\title{
ОНЛАЙН-ОБУЧЕНИЕ РОДИТЕЛЕЙ ДЕТЕЙ С ВПЕРВЫЕ ВЫЯВЛЕННЫМ САХАРНЫМ ДИАБЕТОМ 1 ТИПА В ПЕРИОД КОРОНАВИРУСНОЙ ПАНДЕМИИ
}

\author{
1, 2, 3 Курганович А.В., ${ }^{3,4}$ Майоров А.Ю. \\ 'ГБУЗ ДГП № 125 Департамента здравоохранения г. Москвы, Москва \\ ${ }^{2}$ МРООИ «Диа-Единство», Москва \\ ${ }^{3}$ ОООИ «Российская Диабетическая Ассочиация», Москва \\ ${ }^{4}$ ФГБУ «Национальный медицинский исследовательский центр эндокринологии» Минздрава России, Москва
}

ЦЕль: онлайн-обучение родителей детей с впервые выявленным сахарным диабетом 1 типа в период коронавирусной пандемии.

МАТЕРИАЛЫ И МЕТОДЫ: в связи с пандемией коронавирусной инфекции проект «Впервые выявленный сахарный диабет - адаптация родителей и ребенка», реализуемый МРООИ «Диа-Единство» при поддержке Благотворительного фонда развития филантропии «КАФ» и Программы помощи детям с заболеваниями эндокринной системы «Альфа-Эндо», был проведен в онлайн формате. В проекте приняли участие 64 семьи детей с сахарным диабетом 1 типа, выявленным в 2019-2020 гг. в г. Москве. Возраст

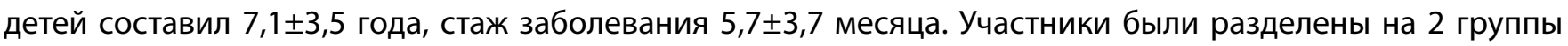
по 32 семьи. В каждой группе было проведено 2 этапа обучения, каждый из которых продолжался 1 месяц. На первом этапе, проходившем в двух группах в апреле и мае 2020 г. соответственно, были проведены обучающие вебинары: 3 по темам «Школы диабета» (инсулинотерапия, питание, самоконтроль гликемии, гипогликемия, физические нагрузки, путешествия), 3 кулинарных практикума с разбором конкретных блюд, которые готовили участники, и подсчетом углеводов в них, а также 3 занятия-тренинга с психологами. Кроме того, все участники были включены в чаты Whats App, где на вопросы «новичков» отвечали опытные родители и врач детский эндокринолог. После летних каникул - в сентябре и октябре 2020 г. в двух группах соответственно, - прошел второй этап проекта, который был направлен на решение практических вопросов с привлечением к вебинарам опытных родителей и профессиональных спортсменов с сахарным диабетом 1 типа. Для проведения вебинаров использовалась платформа ZOOM. Проводилась оценка уровня гликированного гемоглобина $\mathrm{HbA}_{1 с}$ до и после каждого этапа обучения. Кроме того, во время проекта проводилась оценка уровня знаний о диабете отдельно по опросникам для начинающих до и после первого этапа обучения, и по опросникам для опытных родителей до и после второго этапа обучения. В первом опроснике было 27 вопросов, во втором - 25, за каждый правильный ответ присваивался 1 балл.

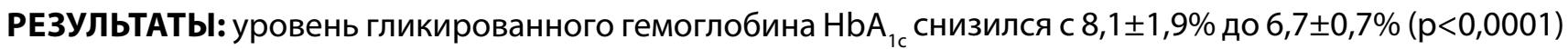
после первого этапа обучения и оставался на том же уровне (6,6士0,9\%) после второго этапа обучения ( $p<0,0001$ по сравнению с исходным, недостоверное отличие $(p=0,37)$ по сравнению с уровнем после первого этапа обучения. Анализ уровня знаний о диабете после проведения первого этапа обучения показал, что увеличилось число родителей, набравших 20 и более баллов: с 33 (51,6\%) до 55 (85,9\%) (p<0,0001). При анализе среднего количества набранных баллов после первого этапа также очевидна положитель-

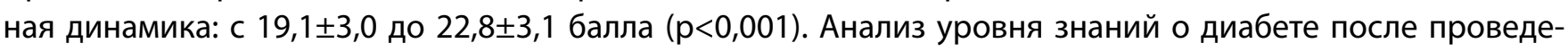
ния второго этапа обучения показал, что увеличилось число родителей, набравших 20 и более баллов: с 25 (39,1\%) до 46 (71,9\%) (р<0,0001). При анализе среднего количества набранных баллов после второго

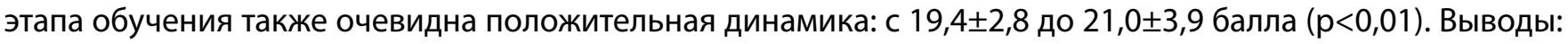
Онлайн обучение родителей детей с впервые выявленным сахарным диабетом 1 типа, является эффективным в отношении гликемического контроля и уровня знаний о диабете. 